\title{
Influence of magnesium and parathyroid hormone on cisplatin-induced nephrotoxicity in esophageal squamous cell carcinoma
}

\author{
HIROTAKA KONISHI ${ }^{*}$, HITOSHI FUJIWARA, HIROSHI ITOH* , ATSUSHI SHIOZAKI, \\ TOMOHIRO ARITA, TOSHIYUKI KOSUGA, RYO MORIMURA, SHUHEI KOMATSU, \\ DAISUKE ICHIKAWA, KAZUMA OKAMOTO and EIGO OTSUJI
}

Division of Digestive Surgery, Department of Surgery, Kyoto Prefectural University of Medicine, Kyoto 602-8566, Japan

Received June 11, 2016; Accepted September 1, 2017

DOI: $10.3892 / 01.2017 .7345$

\begin{abstract}
Magnesium (Mg) supplementation has previously been demonstrated to confer protective effects against nephrotoxicity induced by cisplatin. Parathyroid hormone (PTH) regulates $\mathrm{Mg}$ homeostasis. The aim of present study was to determine the protective effects of $\mathrm{Mg}$ supplementation against cisplatin-induced nephrotoxicity and its association with PTH levels in patients with esophageal squamous cell carcinoma (ESCC). A total of 55 patients with primary ESCC who received chemotherapy with high-dose cisplatin were examined. Mg was administered intravenously, and serum concentrations of PTH, parathyroid hormone-related protein (PTH-rP), creatinine and $\mathrm{Mg}$ were prospectively measured. Of the 55 patients, 37 received $\mathrm{Mg}$ supplementation. Post-chemotherapeutic creatinine concentrations were significantly increased in patients without $\mathrm{Mg}$ supplementation $(\mathrm{P}=0.01)$, with grade 1 and 2 increases of 22.2 and $5.6 \%$, respectively, whereas these increases were suppressed by $\mathrm{Mg}$ supplementation (change in creatinine, $\mathrm{P}=0.21$ ), with grade 1 and 2 increases of 8.1 and $0 \%$, respectively. In addition, PTH and PTH-rP concentrations were high in $8(14.5 \%)$ and $6(10.9 \%)$ of all 55 patients, respectively. Alterations in creatinine concentrations (post-/pre-chemotherapy) due to
\end{abstract}

Correspondence to: Dr Hirotaka Konishi, Division of Digestive Surgery, Department of Surgery, Kyoto Prefectural University of Medicine, 465 Kajii-cho, Kamigyo, Kyoto 602-8566, Japan

E-mail: h-koni7@koto.kpu-m.ac.jp

${ }^{*}$ Contributed equally

Abbreviations: CRT, chemoradiotherapy; ESCC, esophageal squamous cell carcinoma; $\mathrm{Mg}$, magnesium; $\mathrm{PTH}$, parathyroid hormone; PTH-rP, parathyroid hormone-related protein; ULN, upper limit of normal

Key words: cisplatin-induced nephrotoxicity, magnesium, parathyroid hormone, parathyroid hormone-related protein, esophageal squamous cell carcinoma chemotherapy were higher in patients with high levels of PTH regardless of $\mathrm{Mg}$ supplementation $(\mathrm{P}<0.01)$. Pre-therapeutic creatinine concentrations did not correlate with the alterations in creatinine concentrations due to chemotherapy. Intravenous $\mathrm{Mg}$ supplementation therefore conferred protective effects against cisplatin-induced nephrotoxicity in patients with ESCC. Furthermore, increases in PTH or PTH-rP may have influenced the extent of nephrotoxicity.

\section{Introduction}

Esophageal carcinoma is one of the most aggressive types of malignant tumor (1). Multimodal treatments, including neoadjuvant chemotherapy and chemoradiotherapy (CRT), have been demonstrated to improve the survival rate of patients with locally advanced esophageal carcinoma (2). Cisplatin, a representative platinum-containing drug, is a key drug in the chemotherapy of esophageal squamous cell carcinoma (ESCC) and a number of other types of malignancy in Japan (3-5). Cisplatin dose-dependently exerts potent antitumor effects; however, it also induces dose-dependent nephrotoxicity. Cisplatin-induced nephrotoxicity is mild and reversible in the majority of cases, but it can also be severe and irreversible, resulting in the discontinuation of chemotherapy (3).

Hypomagnesemia and renal magnesium $(\mathrm{Mg})$ wasting are established side effects of patients receiving cisplatin-containing chemotherapy $(6,7)$. This $\mathrm{Mg}$ depletion has been demonstrated to further enhance renal platinum accumulation and cisplatin-induced nephrotoxicity. Therefore, oral or intravenous $\mathrm{Mg}$ supplementation can confer renal protective effects against cisplatin-induced nephrotoxicity (8-12).

In normal conditions, the kidney is the principal organ for regulating $\mathrm{Mg}$ homeostasis, and serum $\mathrm{Mg}$ concentrations are maintained within normal ranges by excreting excess $\mathrm{Mg}$ from the serum into urine, a rapid process (13). Due to this strict regulation by the kidney, no hormone is particularly associated with the maintenance of Mg homeostasis; however, large amounts of parathyroid hormone (PTH) influence serum $\mathrm{Mg}$ concentrations by affecting loop of Henle and bone resorption (13). Therefore, PTH or parathyroid hormone-related protein (PTH-rP), which was previously reported to be 
secreted by certain types of tumor cell, including ESCC (14), may influence the physiological regulation of $\mathrm{Mg}$ homeostasis and cisplatin-induced nephrotoxicity in patients receiving chemotherapy.

In the present study, Mg was administered intravenously to patients with ESCC treated with a high-dose cisplatin-containing regimen, and the protective effects of $\mathrm{Mg}$ supplementation against cisplatin-induced nephrotoxicity were prospectively examined in relation to PTH and PTH-rP levels.

\section{Materials and methods}

Patients and treatment courses. A total of 55 patients, including 43 males and 12 females with primary ESCC receiving high-dose cisplatin-containing chemotherapy as neoadjuvant therapy (age range, 47-84 years; median, 66 years), were investigated between January 2013 and December 2014 at the University Hospital, Kyoto Prefectural University of Medicine (Kyoto, Japan). The concentrations of high sensitive PTH, PTH-rP, creatinine and $\mathrm{Mg}$ were measured using in-hospital biochemical tests available for clinical use in all patients before any treatments. The concentrations of creatinine and $\mathrm{Mg}$ were monitored until the next cycle of chemotherapy commenced ( $\sim 3$ weeks). No patients exhibited malnutrition or dehydration during treatment. Clinical and pathological staging were performed according to the criteria of the Japanese Classification of Esophageal Cancer, tenth edition (4), and the Tumor-Node-Metastasis Classification System of the International Union Against Cancer, seventh edition (15).

The present study was conducted in accordance with the principles of the Declaration of Helsinki, and written informed consent for the treatments and data collection was obtained from all patients. Ethical approval from the Facility of Science Committee at the Kyoto Prefectural University of Medicine was not required as the study was an observational study without interpositions with the medical practice necessary for therapeutic purpose.

Cisplatin-containing chemotherapy and Mg supplement regimens. The regimens for the majority of the patients were standard FP [5-fluorouracil $\left(5 \mathrm{FU} ; 800 \mathrm{mg} / \mathrm{m}^{2} /\right.$ day, days $1-5)$ and cisplatin $\left(80 \mathrm{mg} / \mathrm{m}^{2} /\right.$ day, day 1)] (5) or DCF [5FU $\left(700 \mathrm{mg} / \mathrm{m}^{2} /\right.$ day, days $\left.1-5\right)$, cisplatin $\left(70 \mathrm{mg} / \mathrm{m}^{2} /\right.$ day, day 4) and docetaxel $\left(70 \mathrm{mg} / \mathrm{m}^{2} /\right.$ day, day 1)] (16). The modified FP regimen of $5 \mathrm{FU}\left(700 \mathrm{mg} / \mathrm{m}^{2} /\right.$ day, days $\left.1-5\right)$ and cisplatin $\left(70 \mathrm{mg} / \mathrm{m}^{2} /\right.$ day, day 1) was combined with radiotherapy for patients treated with CRT, as previously described (17). The eligibility criteria for these chemotherapy regimens were performance status 0 or 1 , creatinine level $\leq 1.5 \mathrm{mg} / \mathrm{dl}$, and adequate organ function; no age criteria was imposed at the University Hospital, Kyoto Prefectural University of Medicine. Patients treated with $<60 \mathrm{mg} / \mathrm{m}^{2}$ of cisplatin were excluded from the study.

The regimens additionally included pre-hydration with $1,000 \mathrm{ml}$ of saline, a $5 \mathrm{HT}_{3}$ receptor antagonist (palonosetron, $0.75 \mathrm{mg} /$ day, day $1-5)$, aprepitant (125 mg/day, day 1 ; $80 \mathrm{mg} /$ day, day 2-3) and dexamethasone (6.6 mg/day, day 1-5); $8 \mathrm{mEq}$ of magnesium sulfate (day 1) was simultaneously administered within 2-3 h. Following these pre-treatments, high-dose cisplatin was administrated; post-hydration with 2,000 $\mathrm{ml}$ of electrolyte liquid, $60 \mathrm{~g}$ of D-mannitol and $20 \mathrm{mg}$ of furosemide (day 1) were also performed. The electrolyte liquid included sodium, potassium and calcium ions in the external solution.

$\mathrm{Mg}$ supplementation for the patients was not determined at random; patients treated at the Division of Digestive Surgery typically received chemotherapy with $\mathrm{Mg}$ supplementation; however, patients treated at the Division of Gastrointestinal Medicine frequently received chemotherapy without $\mathrm{Mg}$ supplementation. The regimens excluding $\mathrm{Mg}$ supplementation, including hydration or other administrations, were confirmed to be the same between divisions. Appropriate treatments were performed for all hematological and non-hematological adverse events.

Evaluation of nephrotoxicity due to cisplatin. According to a previous study (18), the extent of nephrotoxicity was evaluated by increases in serum creatinine concentrations. A $>1.1$-fold increase in post-therapeutic creatinine concentrations from pre-therapeutic concentrations was defined as an increase. The grade of creatinine increase was indicated according to the National Cancer Institute Common Terminology Criteria for Adverse Events version 4.0 (19), as follows: Grade 1 indicated creatinine concentrations from above the upper limit of normal (ULN) to $\leq 1.5 \mathrm{x}$ ULN; grade 2, $>1.5 \mathrm{x}$ and $\leq 3 \mathrm{x}$ ULN; grade 3 , $>3 \mathrm{x}$ and $\leq 6 \mathrm{x}$ ULN; and grade 4, $>6 \mathrm{x}$ ULN. The most elevated creatinine concentration within the 3 weeks following the first chemotherapy cycle was compared with the pre-therapeutic concentration.

Statistical analysis. Statistical analyses were performed using StatView 5.0J software (SAS Institute, Inc., Cary, NC, USA). The Wilcoxon signed-rank test or Mann-Whitney U test was used to analyze the associations between various biochemical measurements. Spearman's correlation test was used to determine the correlation between pre-therapeutic creatinine concentrations and alterations in creatinine concentration. $\mathrm{P}<0.05$ was considered to indicate a statistically significant difference.

\section{Results}

Patient characteristics. Patient characteristics are included in Table I. All the patients in the present study were diagnosed with SCC. A total of 37 out of the 55 patients received $\mathrm{Mg}$ supplementation; the remaining 18 patients did not. FP was administered to 46 patients, including 5 patients receiving CRT, whereas DCF was administered to 9 patients. FP therapy was more frequent for patients receiving $\mathrm{Mg}$ supplementation $(\mathrm{P}=0.02)$. The majority of the patients were clinically diagnosed with stage II or III disease. No significant differences were observed in clinicopathological features between the 2 groups with and without $\mathrm{Mg}$ supplementation, except for the types of chemotherapy.

Effects of Mg supplementation. Post-chemotherapeutic creatinine concentrations were significantly higher in patients without $\mathrm{Mg}$ supplementation $(\mathrm{P}<0.01$; Fig. $1 \mathrm{~A})$ than with $\mathrm{Mg}$ 
Table I. Characteristics of patients with esophageal squamous cell carcinoma with and without $\mathrm{Mg}$ supplementation.

\begin{tabular}{|c|c|c|}
\hline \multirow[b]{2}{*}{ Characteristics } & \multicolumn{2}{|c|}{ Mg supplementation } \\
\hline & Absent & Present \\
\hline Total & 18 & 37 \\
\hline Age, median (range) & $65(56-75)$ & $67(47-84)$ \\
\hline \multicolumn{3}{|l|}{ Sex } \\
\hline Male & 15 & 28 \\
\hline Female & 3 & 9 \\
\hline \multicolumn{3}{|l|}{ Performance status } \\
\hline 0 & 14 & 29 \\
\hline 1 & 4 & 8 \\
\hline \multicolumn{3}{|l|}{ Chemotherapy } \\
\hline FP alone & 11 & 30 \\
\hline FP chemoradiotherapy & 1 & 4 \\
\hline $\begin{array}{l}\text { Docetaxel, cisplatin and } \\
\text { 5-fluorouracil }\end{array}$ & 6 & 3 \\
\hline \multicolumn{3}{|l|}{ Location } \\
\hline $\begin{array}{l}\text { Cervical or upper thoracic } \\
\text { esophagus }\end{array}$ & 3 & 6 \\
\hline Middle thoracic esophagus & 11 & 21 \\
\hline $\begin{array}{l}\text { Lower thoracic or abdominal } \\
\text { esophagus }\end{array}$ & 4 & 10 \\
\hline \multicolumn{3}{|l|}{ T stage } \\
\hline 1 & 1 & 1 \\
\hline 2 & 1 & 4 \\
\hline 3 & 11 & 28 \\
\hline 4 & 5 & 4 \\
\hline \multicolumn{3}{|l|}{ Lymph node metastasis } \\
\hline Absent & 5 & 13 \\
\hline Present & 13 & 24 \\
\hline \multicolumn{3}{|l|}{ Disease stage } \\
\hline $\mathrm{I}$ & 0 & 1 \\
\hline II & 4 & 11 \\
\hline III & 11 & 23 \\
\hline IV & 3 & 2 \\
\hline
\end{tabular}

$\mathrm{Mg}$, magnesium; FP, 5-fluorouracil and cisplatin.

supplementation $(\mathrm{P}=0.21$; Fig. $1 \mathrm{~B})$. The frequency of creatinine increases due to chemotherapy is included in Table II. In patients without $\mathrm{Mg}$ supplementation, $22.2 \%$ experienced grade 1 and $5.6 \%$, grade 2 creatinine increases, whereas $8.1 \%$ of patients receiving $\mathrm{Mg}$ supplementation experienced grade 1 creatinine increases.

Increases in PTH or PTH-rP and the influence on creatinine concentrations. PTH and PTH-rP were high in 8 (14.5\%) and $6(10.9 \%)$ patients, respectively (Table III). Alterations in creatinine concentration following high-dose cisplatin-containing regimen tended to be higher in the high of PTH or PTH-rP
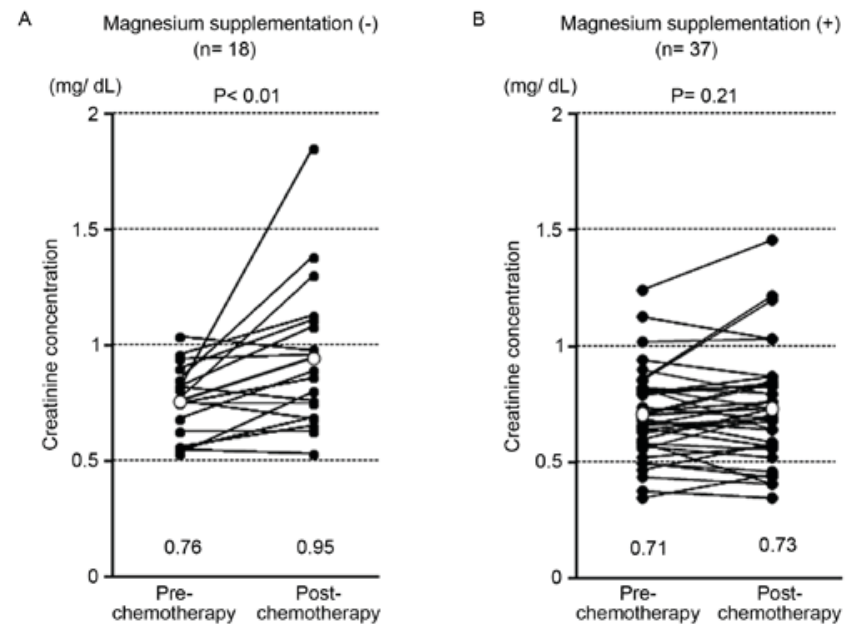

Figure 1. Increase in creatinine concentration pre- and post-chemotherapy. Alterations to creatinine concentrations prior and subsequent to chemotherapy for patients (A) without and (B) with magnesium supplementation. The mean creatinine concentrations are included. The Wilcoxon signed-rank test was used for statistical analysis.

Table II. Patients in the $\mathrm{Mg}$ absent and present groups experiencing an increase in creatinine.

\begin{tabular}{lcc}
\hline & \multicolumn{2}{c}{ Mg supplementation } \\
\cline { 2 - 3 } Increase in creatinine, $\mathrm{n}(\%)$ & Absent & Present \\
\hline Total & 18 & 37 \\
Grade 1 & $4(22.2)$ & $3(8.1)$ \\
Grade 2 & $1(5.6)$ & 0 \\
Grade 3 & 0 & 0 \\
\hline
\end{tabular}

Increase grade determined by the national cancer institute common terminology criteria for adverse effects version 4.0. Mg, magnesium.

Table III. Frequency of increases in PTH or PTH-rP.

\begin{tabular}{lccr}
\hline & \multicolumn{2}{c}{ PTH-rP level, n $(\%)$} & \\
\cline { 2 - 3 } PTH & $\begin{array}{c}\text { Low } \\
\text { level, pg/ml }\end{array}$ & $\begin{array}{c}\text { High } \\
(<1.1 \mathrm{pmol} / \mathrm{l})\end{array}$ & $\begin{array}{r}\text { Total, } \\
(\geq 1.1 \mathrm{pmol} / \mathrm{l})\end{array}$ \\
\hline Low $(<520)$ & $42(76.4)$ & $5(9.1)$ & $47(85.5)$ \\
High $(\geq 520)$ & $7(12.7)$ & $1(1.8)$ & $8(14.5)$ \\
Total & $49(89.1)$ & $6(10.9)$ & \\
\hline
\end{tabular}

PTH, parathyroid hormone; PTH-rP, parathyroid hormone related protein.

level groups than in the low level groups $(\mathrm{P}=0.08$ and $\mathrm{P}=0.04$, respectively; Fig. 2A). These alterations were reduced in patients receiving $\mathrm{Mg}$ supplementation, particularly in the low PTH and PTH-rP level group and the high PTH-rP level group (Fig. 2B). 

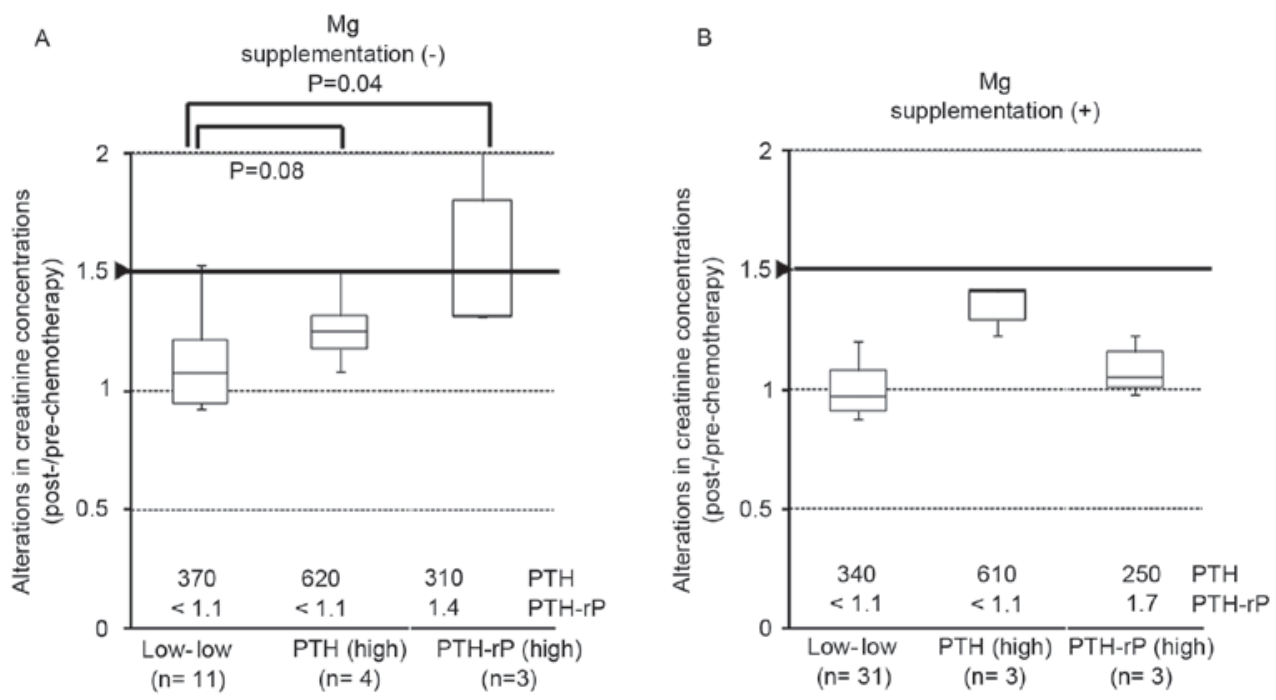

Figure 2. Alterations in creatinine concentrations between patients with low and high levels of PTH or PTH-rP. Alterations in creatinine concentrations prior and subsequent to chemotherapy for patients with low or high levels of PTH and PTH-rP without (A) or with (B) Mg supplementation. The median PTH and PTH-rP values in each group are included. The Mann-Whitney U-test was used for statistical analysis. PTH, parathyroid hormone; PTH-rP, parathyroid hormone related protein; $\mathrm{Mg}$, magnesium.
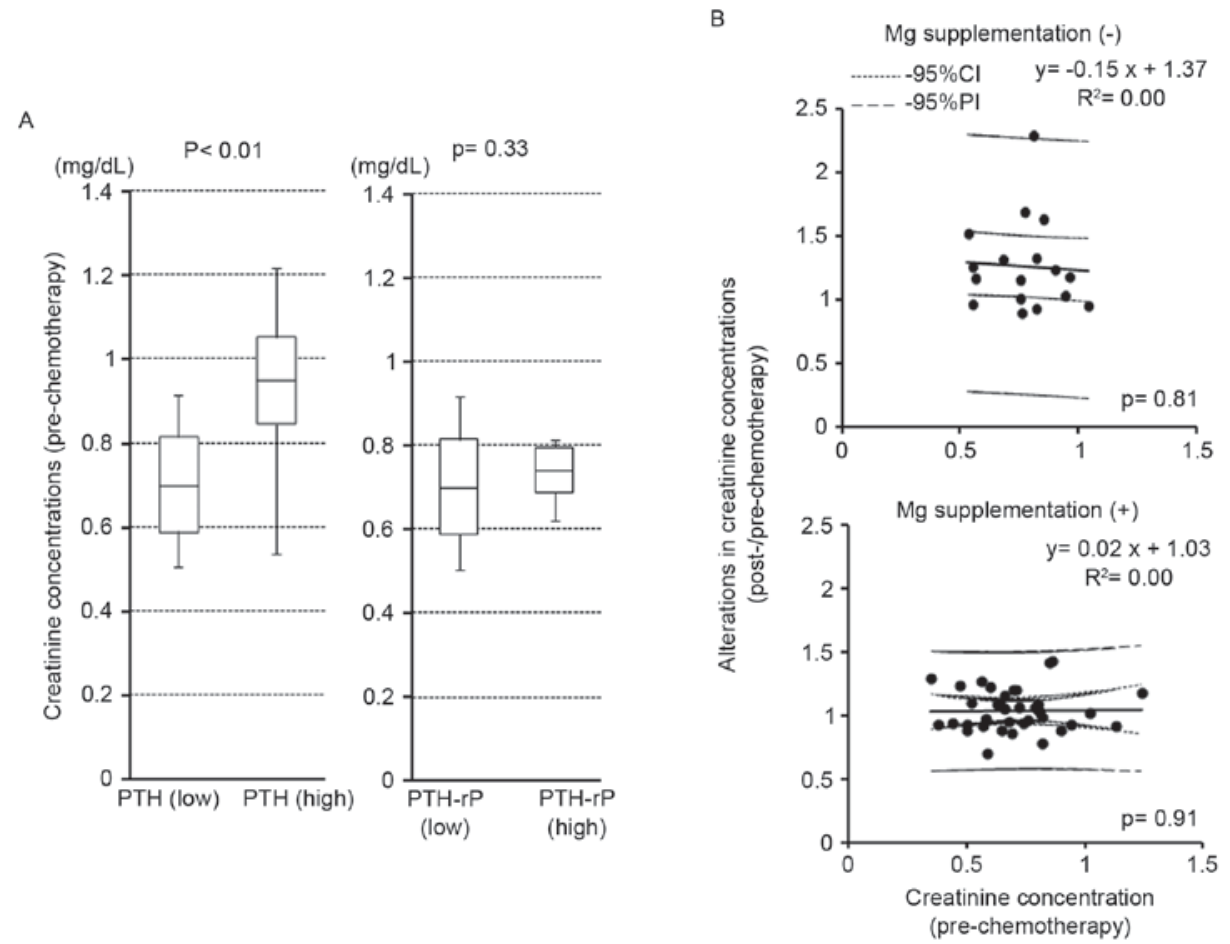

Figure 3. Influence of PTH or PTH-rP levels on pre-therapeutic creatinine concentrations. (A) Association between pre-therapeutic creatinine concentrations and PTH or PTH-rP levels. The Mann-Whitney U-test was used for statistical analyses. (B) Association between pre-therapeutic creatinine concentration and alterations to creatinine concentration were examined using Spearman's correlation test in the patients with or without Mg supplementation. PTH, parathyroid hormone; PTH-rP, parathyroid hormone related protein; $\mathrm{Mg}$, magnesium.

Association of pre-therapeutic creatinine with PTH or PTH-rP levels and creatinine alterations. Pre-therapeutic creatinine concentrations were significantly higher in patients with high levels of PTH (P<0.01; Fig. 3A); however, they did not differ between high and low PTH-rP groups $(\mathrm{P}=0.33$; Fig. 3A). Pre-therapeutic creatinine concentrations did not correlate with the alterations to creatinine concentrations following cisplatin-containing chemotherapy in the patients with or without $\mathrm{Mg}$ supplementation $(\mathrm{P}=0.81$ and $\mathrm{P}=0.91$, respectively; Fig. 3B).

Survival analysis of the patients with or without $\mathrm{Mg}$ supplementation. Mg supplementation did not affect the efficacy of high-dose cisplatin-containing chemotherapy, as the 

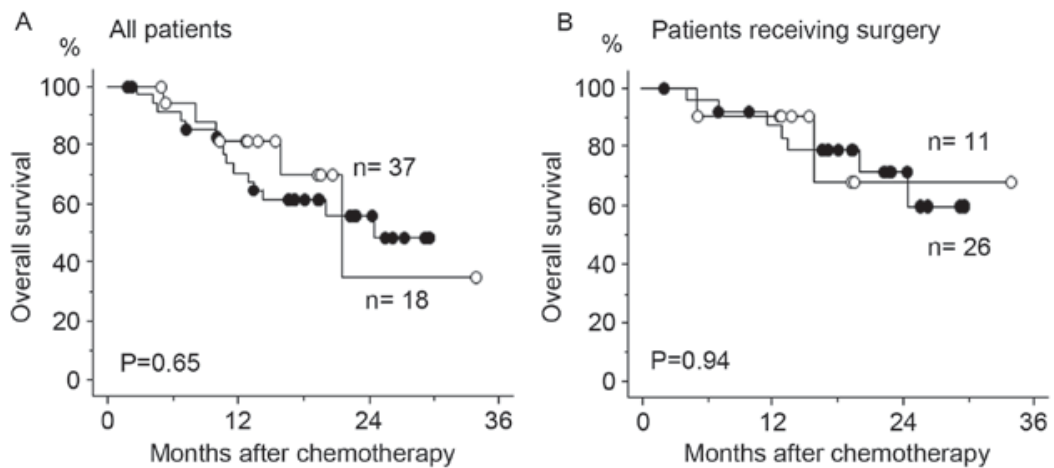

$$
\begin{aligned}
& \longrightarrow \text { Mg supplementation (+) } \\
& -0 \text { - Mg supplementation (-) }
\end{aligned}
$$

Figure 4. Survival analysis of the patients from the present study. The overall survival was analyzed with the Kaplan-Meier method, including (A) all patients with and without $\mathrm{Mg}$ supplementation and (B) the patients who received radical surgery following chemotherapy with and without Mg supplementation. The differences were compared by the stratified log-rank test. $\mathrm{Mg}$, magnesium.

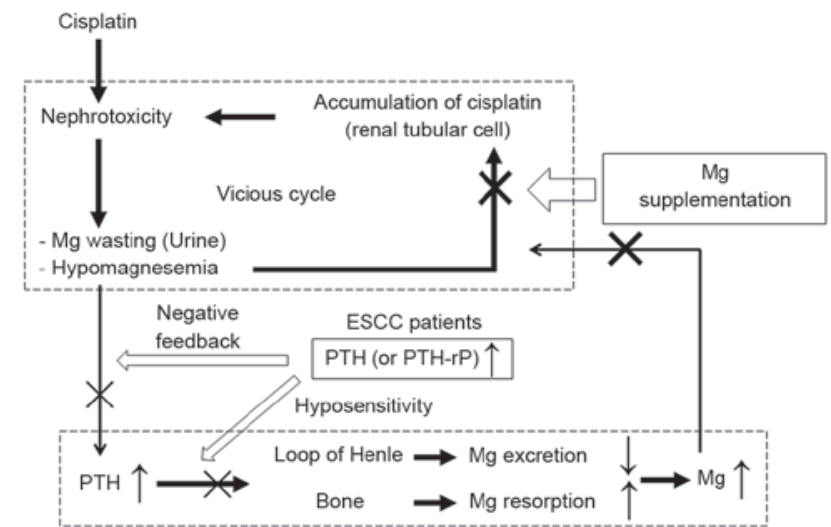

Figure 5. Schema of the present study. The vicious cycle of nephrotoxicity and expected changes in $\mathrm{Mg}$ and PTH levels due to cisplatin-containing chemotherapy are illustrated by dot-line boxes. Mg supplementation may interrupt this vicious cycle. Alternatively, increases in PTH or PTH-rP in patients with ESCC may disrupt the resolution of this vicious cycle as $\mathrm{Mg}$ increase may be interrupted by hyposensitivity or negative feedback to PTH activity. Mg, magnesium; PTH, parathyroid hormone; PTH-rP, parathyroid hormone related protein; ESCC, esophageal squamous cell carcinoma.

overall survival rate was similar between the patients with or without $\mathrm{Mg}$ supplementation regardless of whether surgery was performed subsequent to chemotherapy (Fig. 4).

\section{Discussion}

Cisplatin has been used in combination with other drugs as chemotherapy for various types of malignancy, including digestive tumors (3). The efficacy of administering high-dose cisplatin has been confirmed; however, severe adverse events, including hematotoxicity, anorexia, nausea and nephrotoxicity have been also reported $(3,6,7)$. Large amounts of hydration with saline, mannitol and furosemide are accepted as the standard of care for patients treated with regimens containing high-dose $\left(\geq 60 \mathrm{mg} / \mathrm{m}^{2}\right)$ cisplatin $(3,10,11)$. Previous studies have demonstrated that $\mathrm{Mg}$ supplementation also confers protective effects against cisplatin-induced nephrotoxicity (10,20-22).

In the present study, the focus was on intravenous $\mathrm{Mg}$ supplementation for patients with ESCC treated with high-dose cisplatin. The results obtained confirmed that increases in post-chemotherapeutic creatinine concentrations were significantly suppressed by magnesium supplementation (Fig. 1 and Table II). The protective effects of oral or intravenous $\mathrm{Mg}$ supplementation against cisplatin-induced nephrotoxicity have been reported in various types of malignancy, including in lung (10-12), head and neck $(10,23,24)$, digestive $(8,10)$, testicular $(25)$, ovarian $(9,24)$ and bladder $(24)$ cancer. However, just a limited number of clinical reports have demonstrated the protective effects of intravenous $\mathrm{Mg}$ supplementation against cisplatin-induced nephrotoxicity in ESCC (10).

PTH or PTH-rP levels in patients with ESCC were also considered; an association between increases in post-therapeutic creatinine concentrations and high levels of PTH was identified (Fig. 2). Previous studies reported that PTH-rP was expressed in a range of types of cancer, particularly ESCC and lung cancer, and mimicked the effects of PTH $(14,26,27)$. In normal conditions, PTH is not an important physiological regulator of $\mathrm{Mg}$ homeostasis as renal regulation is, relatively, much more efficacious. However, it has been suggested that a large amount of PTH regulates serum $\mathrm{Mg}$ concentrations by decreasing urinary $\mathrm{Mg}$ excretion through influences on loop of Henle and bone resorption (13).

Fig. 5 is a schema for the rationale of the present study. Cisplatin induces renal $\mathrm{Mg}$ wasting and hypomagnesemia through its renal toxicity by directly injuring the mechanisms of $\mathrm{Mg}$ reabsorption $(6,7,28)$. Hypomagnesemia reduces the expression of certain transporters in renal tubules in order to maintain serum $\mathrm{Mg}$ concentrations. This reduction in tubular transporters also amplifies the renal accumulation of cisplatin, which is accompanied by further nephrotoxicity (20-22). In this vicious cycle, we hypothesize that $\mathrm{Mg}$ supplementation protects against nephrotoxicity by blocking the augmented accumulation of cisplatin.

Alternatively, reductions in serum $\mathrm{Mg}$ levels due to cisplatin will induce increases in parathyroid hormone and serum $\mathrm{Mg}$ in order to resolve nephrotoxicity (Fig. 5). In patients with ESCC with high levels of PTH or PTH-rP, we hypothesize that rapid serum $\mathrm{Mg}$ increase will be disrupted by hyposensitivity to increases in PTH (29) or a negative-feedback mechanism 
for lowering serum $\mathrm{Mg}(30,31)$, also implicated in calcium regulation. Therefore, patients with higher levels of PTH or PTH-rP may have more difficulties with hypomagnesemia and suppressing cisplatin-induced nephrotoxicity than patients with lower PTH or PTH-rP levels.

Approximately $8 \mathrm{mEq}$ of $\mathrm{Mg}$ is excreted into the urine each day and reabsorbed during $\mathrm{Mg}$ deprivation (13). On this basis, $8 \mathrm{mEq}$ of magnesium sulfate was administered prior to the administration of cisplatin, which was demonstrated to be similar to the volume excreted each day in a previous study (11). However, it currently remains unclear whether the volume and route of supplemented $\mathrm{Mg}$ was adequate.

Kidera et al (10) suggested that Mg supplementation was effective for protecting against renal toxicity induced by cisplatin. They also demonstrated that nephrotoxicity was more likely for patients with esophageal cancer. Although detailed tissue types were not considered in the present study, the results regarding increases in PTH or PTH-rP levels in patients with ESCC may be associated with this specificity. However, previous studies reported that $\mathrm{Mg}$ supplementation did not affect the tumor response to cisplatin-based chemotherapy $(9,11,25)$. It was also concluded in the present study that $\mathrm{Mg}$ supplementation did not affect the efficacy of cisplatin-containing chemotherapy, as the overall survival time was similar between the patients with or without $\mathrm{Mg}$ supplementation (Fig. 4).

However, certain points in the present study remain undetermined. The reason why the level of PTH was increased in patients with ESCC was not identified. In addition to high sensitive PTH, the level of intact PTH was also measured, and the frequency of its increase being detected was low (data not shown). The frequency of intact PTH or PTH-rP increase was markedly lower than high sensitive $\mathrm{PTH}$, although the results of high sensitive PTH may be influenced by other PTH subtypes, including PTH-rP, due to their similar structures. Although the levels of PTH and PTH-rP were analyzed separately in the present study, their effects on creatinine increases may be similar.

Alternatively, PTH levels may be influenced by chronic renal dysfunction. In the present study, pre-therapeutic creatinine concentrations were significantly higher in the patients with high levels of $\mathrm{PTH}$, and not for patients with high levels of PTH-rP (Fig. 3A). The effects of Mg supplementation on creatinine alterations were also slightly different between patients with high levels of PTH and PTH-rP. These results require further investigation in order to confirm the influence of PTH or PTH-rP on cisplatin-induced nephrotoxicity.

In conclusion, although performed on a small scale, the present prospective study revealed that intravenous magnesium supplementation conferred protective effects against cisplatin-induced nephrotoxicity in patients with ESCC. Furthermore, increases in PTH or PTH-rP levels may influence nephrotoxicity.

\section{References}

1. Hofstetter W, Swisher SG, Correa AM, Hess K, Putnam JB Jr Ajani JA, Dolormente M, Francisco R, Komaki RR, Lara A, et al: Treatment outcomes of resected esophageal cancer. Ann Surg 236: 376-384, 2002.
2. Sjoquist KM, Burmeister BH, Smithers BM, Zalcberg JR, Simes RJ, Barbour A and Gebski V; Australasian Gastro-Intestinal Trials Group: Survival after neoadjuvant chemotherapy or chemoradiotherapy for resectable oesophageal carcinoma: An updated meta-analysis. Lancet Oncol 12: 681-692, 2011.

3. Wang D and Lippard SJ: Cellular processing of platinum anticancer drugs. Nat Rev Drug Discov 4: 307-320, 2005.

4. Japanese Society for Esophageal Diseases: Japanese Classification of Esophageal Cancer. 10th edition. Kanehara \& Co., Ltd., Tokyo, Japan, 2007.

5. Ando N, Kato H, Igaki H, Shinoda M, Ozawa S, Shimizu H, Nakamura T, Yabusaki H, Aoyama N, Kurita A, et al: A randomized trial comparing postoperative adjuvant chemotherapy with cisplatin and 5-fluorouracil versus preoperative chemotherapy for localized advanced squamous cell carcinoma of the thoracic esophagus (JCOG9907). Ann Surg Oncol 19: 68-74, 2012.

6. Lajer H and Daugaard G: Cisplatin and hypomagnesemia. Cancer Treat Rev 25: 47-58, 1999.

7. Lam M and Adelstein DJ: Hypomagnesemia and renal magnesium wasting in patients treated with cisplatin. Am J Kidney Dis 8: 164-169, 1986.

8. Evans TR, Harper CL, Beveridge IG, Wastnage R and Mansi JL: A randomised study to determine whether routine intravenous magnesium supplements are necessary in patients receiving cisplatin chemotherapy with continuous infusion 5-fluorouracil. Eur J Cancer 31A: 174-178, 1995.

9. Bodnar L, Wcislo G, Gasowska-Bodnar A, Synowiec A, Szarlej-Wcisło K and Szczylik C: Renal protection with magnesium subcarbonate and magnesium sulphate in patients with epithelial ovarian cancer after cisplatin and paclitaxel chemotherapy: A randomised phase II study. Eur J Cancer 44: 2608-2614, 2008

10. Kidera Y, Kawakami H, Sakiyama T, Okamoto K, Tanaka K, Takeda M, Kaneda H, Nishina S, Tsurutani J, Fujiwara K, et al: Risk factors for cisplatin-induced nephrotoxicity and potential of magnesium supplementation for renal protection. PLoS One 9: e101902, 2014.

11. Muraki K, Koyama R, Honma Y, Yagishita S, Shukuya T, Ohashi R, Takahashi F, Kido K, Iwakami S, Sasaki S, et al: Hydration with magnesium and mannitol without furosemide prevents the nephrotoxicity induced by cisplatin and pemetrexed in patients with advanced non-small cell lung cancer. J Thorac Dis 4: 562-568, 2012.

12. Yoshida T, Niho S, Toda M, Goto K, Yoh K, Umemura S, Matsumoto S, Ohmatsu $\mathrm{H}$ and Ohe Y: Protective effect of magnesium preloading on cisplatin-induced nephrotoxicity: A retrospective study. Jpn J Clin Oncol 44: 346-354, 2014.

13. Rude RK: Magnesium metabolism and deficiency. Endocrinol Metab Clin North Am 22: 377-395, 1993.

14. Rabbani SA: Molecular mechanism of action of parathyroid hormone related peptide in hypercalcemia of malignancy: Therapeutic strategies (Review). Int J Oncol 16: 197-206, 2000.

15. Sobin LH, Gospodarowicz MK and Wittekind C (eds): International Union Against Cancer: TNM Classification of Malignant Tumours. 7th edition. Wiley-Blackwell, Hoboken, NJ, pp66-72, 2010 .

16. Hara H, Tahara M, Daiko H, Kato K, Igaki H, Kadowaki S, Tanaka Y, Hamamoto Y, Matsushita H, Nagase M and Hosoya Y: Phase II feasibility study of preoperative chemotherapy with docetaxel, cisplatin, and fluorouracil for esophageal squamous cell carcinoma. Cancer Sci 104: 1455-1460, 2013.

17. Ishida K, Ando N, Yamamoto S, Ide H and Shinoda M: Phase II study of cisplatin and 5-fluorouracil with concurrent radiotherapy in advanced squamous cell carcinoma of the esophagus: A Japan Esophageal Oncology Group (JEOG)/Japan Clinical Oncology Group trial (JCOG9516). Jpn J Clin Oncol 34: 615-619, 2004.

18. Stewart DJ, Dulberg CS, Mikhael NZ, Redmond MD, Montpetit VA and Goel R: Association of cisplatin nephrotoxicity with patient characteristics and cisplatin administration methods. Cancer Chemother Pharmacol 40: 293-308, 1997.

19. National Cancer Institute: Common Terminology Criteria for Adverse Events v.3.0 and v.4.0 (CTCAE), 2011. http://ctep.cancer. gov/protocolDevelopment/electronic_applications/ctc.htm.

20. Lajer H, Kristensen M, Hansen $\mathrm{HH}$, Nielsen S, Frøkiaer J, Ostergaard LF, Christensen S, Daugaard G and Jonassen TE: Magnesium depletion enhances cisplatin-induced nephrotoxicity. Cancer Chemother Pharmacol 56: 535-542, 2005. 
21. van Angelen AA, Glaudemans B, van der Kemp AW, Hoenderop JG and Bindels RJ: Cisplatin-induced injury of the renal distal convoluted tubule is associated with hypomagnesaemia in mice. Nephrol Dial Transplant 28: 879-889, 2013.

22. Solanki MH, Chatterjee PK, Gupta M, Xue X, Plagov A, Metz MH, Mintz R, Singhal PC and Metz CN: Magnesium protects against cisplatin-induced acute kidney injury by regulating platinum accumulation. Am J Physiol Renal Physiol 307: F369-F384, 2014.

23. Vokes EE, Mick R, Vogelzang NJ, Geiser R and Douglas F: A randomised study comparing intermittent to continuous administration of magnesium aspartate hydrochloride in cisplatin-induced hypomagnesaemia. Br J Cancer 62: 1015-1017, 1990.

24. Martin M, Diaz-Rubio E, Casado A, López Vega JM, Sastre J and Almenarez J: Intravenous and oral magnesium supplementations in the prophylaxis of cisplatin-induced hypomagnesemia Results of a controlled trial. Am J Clin Oncol 15: 348-351, 1992.

25. Willox JC, McAllister EJ, Sangster G and Kaye SB: Effects of magnesium supplementation in testicular cancer patients receiving cis-platin: A randomised trial. Br J Cancer 54: 19-23, 1986.

26. Carney SL, Ray C, Ebeling PR, Martin TJ and Gillies AH: Synthetic human parathyroid hormone-related protein and rat renal electrolyte transport. Miner Electrolyte Metab 17: 41-45, 1991.
27. Jaïs P, Bouizar Z, Binn M, Vissuzaine C, Hayem G, Mignon M and Lewin MJ: Parathyroid hormone-related protein in an esophageal squamous cell carcinoma with tumor-induced hypercalcemia. Am J Gastroenterol 92: 343-346, 1997.

28. Arany I and Safirstein RL: Cisplatin nephrotoxicity. Semin Nephrol 23: 460-464, 2003

29. Naafs MA, Hackeng WH, Koorevaar G and Silberbusch J: Abnormal responsiveness of nephrogenous cyclic AMP excretion following intravenously administered calcium in normocalcaemic squamous cell cancer patients. Bone Miner 4: 289-298, 1988.

30. Suh SM, Tashjian AH Jr, Matsuo N, Parkinson DK and Fraser D: Pathogenesis of hypocalcemia in primary hypomagnesemia: Normal end-organ responsiveness to parathyroid hormone, impaired parathyroid gland function. J Clin Invest 52: 153-160, 1973.

31. Yap AS, Mortimer RH, Jacobi JM, Galligan JP, Perry-Keene DA and Khafagi FA: Blunted parathyroid response to correction of hypercalcemia in subjects with squamous cell carcinoma. Horm Res 40: 222-226, 1993. 